\title{
PENGEMBANGAN MULTIMEDIA INTERAKTIF UNTUK MATA PELAJARAN ILMU PENGETAHUAN SOSIAL (IPS) SEKOLAH DASAR KELAS V
}

\author{
INTERACTIVE MULTIMEDIA DEVELOPMENT \\ FOR LESSON SOCIAL SCIENCES (IPS) FIFTH GRADE ELEMENTARY SCHOOL
}

\author{
Arif Mahya Fanny, Siti Partini Suardiman \\ Universitas Veteran Bangun Nusantara, Universitas Negeri Yogyakarta \\ arifmahyafanny@gmail.com, -
}

\begin{abstract}
Abstrak
Penelitian ini bertujuan untuk: (1) mengembangkan multimedia interaktif sebagai media pembelajaran IPS kelas V dengan materi peristiwa sekitar proklamasi dan (2) mengetahui kelayakan produk dari aspek materi, aspek tampilan dan aspek kemenarikan untuk pembelajaran IPS SD. Dilaksanakan melalui beberapa tahapan, tahap pertama adalah pendahuluan yang meliputi studi pustaka dan studi lapangan, tahap kedua pengembangan yang meliputi perencanaan dan pengembangan produk awal. Tahap ketiga uji lapangan meliputi uji coba preliminary field test, main field test dan operational field test. Hasil validasi oleh ahli media dan ahli materi menunjukkan bahwa kelayakan multimedia pembelajaran IPS pada aspek media sebesar 4,23 (sangat baik) dan kelayakan pada aspek materi sebesar 4,26 (sangat baik). Hasil uji coba lapangan menunjukan bahwa tanggapan siswa terhadap kelayakan multimedia dengan rerata skor 4,08 (baik). Hasil tersebut menunjukkan bahwa multimedia pembelajaran IPS yang dikembangkan layak digunakan dalam kegiatan pembelajaran dan menjadi alternatif sumber belajar IPS khususnya siswa kelas V dengan materi peristiwa sekitar proklamasi.
\end{abstract}

Kata kunci: Pengembangan, Media Pembelajaran, Multimedia Interaktif, Ilmu Pengetahuan Sosial.

\begin{abstract}
The research aimed to: (1) develop an interactive multimedia as learning media of social science for fifth grade students with the materials of events around proclamation; and (2) find the product eligibility from the aspect of material, appearance, and attractiveness for the learning of elementary school social science. The research was conducted through several stages. The first stage was introduction that included library study and field study. The second stage was development that included initial product planning and development. The third stage was field testing that included preliminary field test, main field test and operational field test. The results of validation conducted by media expert and material expert showed that the eligibility of learning multimedia for social science on the aspect of media was 4.23 (very good) and the eligibility of learning multimedia for social science on the aspect of material was 4.26 (very good). The results of field testing showed that the students' response toward the multimedia eligibility was 4.08 (very good). These results showed that the learning multimedia for social science was eligible to be implemented in the learning activities and might become an alternative of social science learning resource especially for the fifth grade students with materials of events around proclamation.
\end{abstract}

Keywords: Development, Learning Media, Interactive Multimedia, Social Science 


\section{Pendahuluan}

Setiap kegiatan pembelajaran harus dilakukan secara sistematik, sistem pembelajaran IPS mengintegrasikan berbagai komponen pembelajaran untuk mencapai tujuan pendidikan nasional pada umumnya dan tujuan pembelajaran IPS pada khususnya. Komponen-komponen pembelajaran harus saling mendukung untuk menciptakan suasana pembelajaran yang menyenangkan dan interaktif.

Belajar adalah cara di mana seorang individu mengubah cara dia mengkonsepsualisasikan dunia. Seperti yang dikemukakan Kennedy (2007, p.1)

Traditionally the settings for academic learning have been in the form of lectures, tutorials, practical classes, problem solving exercises and assignments. The development of IMM for learning has generally been seen primarily as an extra learning opportunity for students, either in the form of a self-paced tutorial done in the student's own time or as an aid to revision. Only limited examples exist where IMM has replaced part of the traditional approach to academic learning in higher education.

Secara tradisional pengaturan untuk pembelajaran akademis masih dalam bentuk ceramah, tutorial, kelas praktis, pemecahan masalah latihan dan penugasan. Pengembangan Interactive multimedia (IMM) untuk belajar secara umumnya dipandang sebagai kesempatan belajar tambahan bagi siswa, baik dalam bentuk tutorial maupun dilakukan secara mandiri atau sebagai bantuan untuk revisi. Hanya contoh di mana Interactive multimedia (IMM) telah menggantikan bagian dari pendekatan tradisional untuk pembelajaran akademis dengan menggunakan anggaran pendidikan yang cukup tinggi.

Permasalahan yang sedang dihadapi sekolah di Indonesia saat ini adalah minimnya ketersediaan software pembelajaran IPS kelas V dalam bentuk multimedia interaktif. Pendidik dalam pembelajaran IPS masih banyak menggunakan media cetak seperti buku paket, modul, LKS. Di samping itu pendidik belum mam$\mathrm{pu}$ membuat dan mengembangkan software pembelajaran multimedia interaktif yang dapat membuat peserta didik tidak hanya memperhatikan media atau objek saja, melainkan juga dituntut untuk berinteraksi selama mengikuti pembelajaran.
Seiring dengan pesatnya perkembangan media informasi dan komunikasi, baik perangkat keras (hardware) maupun perangkat lunak (software), telah mengakibatkan bergesernya peran guru. Guru tidak bisa lagi berperan sebagai satu-satunya sumber informasi bagi kegiatan pembelajaran para siswa oleh karena itu guru membutuhkan media yang bisa dimanfaatkan sebagai sumber informasi alternatif. Salah satu produk teknologi yang dapat digunakan sebagai media dalam pembelajaran adalah komputer. Keberadaan komputer saat ini telah membantu guru berbagai kepentingan terkait dengan tugasnya dalam merancang, melaksanakan dan mengevaluasi pembelajaran. Komputer telah banyak digunakan dalam proses belajar mengajar, dengan satu tujuan mutu pendidikan akan selangkah lebih maju seiring dengan kemajuan teknologi.

Dengan pembelajaran berbasis komputer, diharapkan dapat membantu pembelajar yang memiliki kecepatan belajar lebih lambat (slow learner) agar dapat belajar secara efektif, karena dengan komputer untuk menayangkan kembali informasi yang diperlukan, sedangkan bagi pembelajar yang lebih cepat (fast learner) dapat memacu aktifitas belajar (Bambang Warsita, 2008, p.138).

Keindahan, kemenarikan dan adanya interaktivitas dalam suatu media pembelajaran merupakan sarana agar peserta didik tidak jenuh dalam mengikuti pelajaran dan efek yang terbesar diharapkan peserta didik dapat termotivasi dan mempermudah dalam menerima materi pelajaran, disamping itu belajar dapat dilakukan di sekolah maupun di rumah. Oleh karena itu, peneliti tertarik untuk mengembangkan Multimedia Interaktif untuk mata pelajaran Ilmu Pengetahuan Sosial (IPS) sekolah dasar Kelas V.

Berdasarkan uraian tersebut, dapat diidentifikasi masalah-masalah dalam proses pembelajaran IPS yaitu belum tersedianya software untuk pembelajaran IPS khususnya kelas $\mathrm{V}$ dalam bentuk multimedia interaktif, pembelajaran IPS dianggap sulit dan kurang menarik oleh peserta didik, guru belum begitu optimal menggunakan media dalam pembelajaran IPS, pendidik belum mampu membuat dan mengembangkan software pembelajaran multimedia interaktif.

Sesuai dengan permasalahan tersebut di atas maka, penelitian ini bertujuan mengembangkan multimedia interaktif sebagai media pembelajaran IPS sekolah dasar kelas V yang 
layak, menguji kelayakan produk di tinjau dari aspek pembelajaran, aspek materi/isi, aspek media.

Hasil penelitian ini diharapkan dapat memberikan manfaat di antaranya adalah manfaat teoritis yang secara teoritis penelitian pengembangan ini dapat dijadikan pedoman referensi awal bagi penelitian berikutnya yang ingin mengembangkan media pembelajaran dalam bentuk multimedia interaktif yang kemudian dapat dijadikan suatu pertimbangan dalam hal memperbaiki kualitas pembelajaran IPS. Kemudian manfaat praktis, hasil penelitian ini diharapkan juga memberikan manfaat secara praktis untuk guru guna memberikan manfaat sebagai media pembelajaran alternatif yang dapat digunakan dalam proses pembelajaran juga memotivasi guru untuk meningkatkan penggunaan komputer untuk pembelajaran di sekolah dan bagi siswa sebagai bahan belajar dan bisa digunakan sebagai pembelajaran secara mandiri serta membantu pemahaman siswa terhadap materi pelajaran, juga agar membiasakan siswa untuk menggunakan komputer yang sangat dibutuhkan masa sekarang dan mendatang. Selanjutnya untuk sekolah memberikan produk multimedia pembelajaran interaktif untuk mata pelajaran IPS kelas V dan menambah koleksi media pembelajaran khususnya mata pelajaran IPS serta hasil penelitian ini juga dapat digunakan sebagai salah satu inspirasi dalam melakukan inovasi pembelajaran pada mata pelajaran yang lain.

\section{Metode}

Berisi jenis penelitian, waktu dan tempat penelitian, target/sasaran, subjek penelitian, prosedur, instrumen dan teknik analisis data serta hal-hal lain yang berkait dengan cara penelitiannya. target/sasaran, subjek penelitian, prosedur, data dan instrumen, dan teknik pengumpulan data, serta teknik analisis data serta hal-hal lain yang berkait dengan cara penelitiannya dapat ditulis dalam sub-subbab, dengan sub-subheading. Sub-subjudul tidak perlu diberi notasi, namun ditulis dengan huruf kecil berawalkan huruf kapital, TNR-11 bold, rata kiri. Sebagai contoh dapat dilihat berikut.

\section{Jenis Penelitian}

Jenis penelitian ini adalah penelitian dan pengembangan atau Research and Development (R\&D), dalam penelitian ini dikembangkan produk berupa multimedia interaktif untuk pembelajaran IPS kelas V sekolah dasar. Pene- litian pengembangan dalam dunia pendidikan banyak digunakan untuk mencari solusi dari permasalahan praktis dalam dunia pendidikan.

\section{Waktu dan Tempat Penelitian}

Pengembangan multimedia interaktif diawali dengan melakukan studi pendahuluan pada bulan April 2012 di SDN Lempuyangan 1 Yogyakarta.

\section{Target/Subjek Penelitian}

Subjek ujicoba atau responden yang terlibat dalam penelitian ini adalah siswa-siswi SD Negeri Lempuyangan 1 kelas V. Pengambilan sampel sebagai subjek uji coba secara random (acak), dengan cara mengundi dari jumlah keseluruhan siswa kelas V. Setiap siswa mempunyai peluang yang sama untuk dipilih menjadi subjek uji coba. Jumlah yang menjadi subjek uji coba sebanyak 35 siswa

\section{Prosedur}

Secara garis besar, langkah-langkah pengembangan meliputi analisis kebutuhan, desain pembelajaran, produksi/pengembangan media, dan evaluasi produk.

Analisis kebutuhan meliputi studi lapangan dan studi pustaka. Studi lapangan di antaranya observasi dan wawancara. Observasi ini dilakukan untuk mengetahui secara langsung kondisi/keadaan sekolah dan proses pembelajaran IPS di SD Negeri Lempuyangan 1 dan wawancara dilakukan kepada guru mata pelajaran IPS pada bulan Maret Kegiatan ini dilakukan untuk mengetahui kebutuhan para siswa dan guru tentang materi atau pokok bahasan dalam mata pelajaran IPS yang dirasakan sulit untuk dipelajari dan dikuasai oleh siswa atau diajarkan oleh guru, dan jenis media yang paling cocok atau paling sesuai untuk dikembangkan. Sedangkan studi pustaka meliputi studi kurikulum, silabus mata pelajaran IPS, buku-buku teks yang berkaitan dengan materi dalam produk, buku-buku teks mengenai teori belajar dan teori pembelajaran yang melandasi pengembangan multimedia interaktif, buku-buku pelajaran IPS.

Desain pembelajaran, kegiatan yang dilakukan adalah menentukan standar kompetensi, kompetensi dasar, dan indikator keberhasilan, mengembangkan butir-butir evaluasi, mengembangkan dan memilih materi pelajaran untuk pengembangan multimedia pembelajaran. Setelah dilakukan identifikasi materi pembelajaran yang dikembangkan, selanjutnya disusun desain 
produk multimedia pembelajaran dengan cara membuat flowchart view dan storyboard. Kemudian mengumpulkan bahan-bahan pendukung seperti foto, video, audio, animasi, clip art image, dan gambar.

Memproduksi multimedia adalah setelah bahan-bahan yang diperlukan dalam pengembangan multimedia interaktif terkumpul, selanjutnya dimasukkan semua bahan/materi yang telah terkumpul tersebut ke dalam aplikasi program komputer menggunakan authoring system, yaitu program Autoplay yang mengacu pada flowchart dan storyboard. Kegiatan selanjutnya adalah dilakukan pengetesan secara modular, peneliti melakukan pengetesan program pembelajaran yang telah dibuat tersebut untuk memastikan apakah hasilnya sesuai yang dikehendaki. Hasilnya program pembelajaran yang dibuat tersebut dapat dioperasikan dengan lancar. Kemudian peneliti mengemas program multimedia interaktif tersebut ke dalam sebuah Compact Disc (CD) pembelajaran. Akhirnya, produk awal (CD) multimedia interaktif mata pelajaran IPS telah terwujud.

Evaluasi produk adalah memvalidasi/ mengevaluasi produk yang telah dikembangkan. Mengevaluasi produk pembelajaran ini mengacu pada pendapat Arief S. Sadiman, dkk (2009, pp.182-187) dan Dick \& Carey (2005, pp.282-291) dengan cara memvalidasi produk pembelajaran kepada ahli media dan ahli materi, dilanjutkan dengan analisis dan revisi produk berdasarkan saran ahli media dan ahli materi, sehingga produk pembelajaran tersebut dinyatakan valid atau layak oleh baik ahli media maupun ahli materi. Kemudian dengan melakukan uji coba produk pembelajaran kepada user (siswa), yaitu uji coba satu-satu (one to one evaluation). Sebanyak 3 siswa, dilanjutkan dengan analisis dan revisi produk berdasarkan hasil uji coba satu-satu (one to one evaluation). Uji coba selanjutnya yaitu uji coba kelompok kecil (small group evaluation) sebanyak 10 siswa dilanjutkan dengan analisis dan revisi produk berdasarkan hasil uji coba kelompok kecil tersebut. Kemudian ujicoba terakhir yaitu uji coba lapangan (field evaluation) sebanyak 22 siswa, dilanjutkan dengan analisis dan revisi produk berdasarkan hasil uji coba lapangan sehingga menghasilkan produk akhir.

Data, Intrumen, dan Teknik Pengumpulan Data

Uji coba dilakukan untuk mengumpulkan data evaluasi yang digunakan sebagai dasar menetapkan tingkat kualitas dan kelayakan produk multimedia yang dikembangkan. Data hasil evaluasi yang berasal dari ahli media, ahli materi dan siswa yang berupa data kuantitatif selanjutnya dianalisis dan dikonversikan ke dalam data kualitatif sehingga diketahui tingkat kelayakan multimedia interaktif sebagai media pembelajaran IPS. Adapun jenis data yang meliputi aspek pembelajaran dan materi/isi dari ahli materi, aspek media dari ahli media, aspek pembelajaran, materi, dan media dari siswa.

Untuk menghasilkan produk pengembangan yang berkualitas diperlukan instrumen yang mampu menggali data yang diperlukan dalam pengembangan produk multimedia interaktif. Instrumen yang digunakan untuk mengumpulkan data pada penelitian ini berupa lembar validasi ahli, lembar observasi dan kuesioner. Lembar validasi digunakan untuk mengukur/mengevaluasi kualitas produk yang dikembangkan dari aspek media oleh ahli media dan aspek materi oleh ahli materi. Lembar kuesioner digunakan untuk mengukur/mengevaluasi kualitas produk yang dikembangkan dari aspek pembelajaran, aspek materi, dan aspek media oleh siswa.

Sesuai keperluan di atas, kemudian dikembangkan indikator-indikator kualitas multimedia interaktif pembelajaran baik dari aspek pembelajaran, tampilan dan isi/materi dengan mengacu pada teori dan pendapat para ahli sesuai bidangnya. Berdasarkan kisi-kisi tersebut kemudian dikembangkan instrumen penelitian. Untuk mendapatkan instrumen yang digunakan, langkah-langkah yang ditempuh adalah sebagai berikut: (a) Menyusun kisi-kisi instrumen. (b) Mengonsultasikan kisi-kisi instrumen yang telah dibuat kepada dosen pembimbing. (c) Menyusun butir-butir instrumen berdasarkan kisikisi instrumen. (d) Mengonsultasikan instrumen kepada dosen pembimbing.

\section{Teknik Analisis Data}

Data hasil penelitian ini adalah berupa tanggapan ahli media, ahli materi dan siswa terhadap kualitas produk yang telah dikembangkan ditinjau dari aspek media dan aspek materi. Data berupa komentar, saran revisi dan hasil pengamatan peneliti selama proses uji coba dan ditindak lanjuti secara deskriptif kualitatif, dan disimpulkan sebagai masukan untuk memperbaiki atau merevisi produk yang telah dikembangkan. Sementara, data berupa skor tanggapan ahli media, ahli materi dan siswa yang diperoleh melaluai kuesioner, dianalisis 
secara deskriptif kuantitatif dengan teknik persentase dan kategorisasi.

Langkah-langkah yang digunakan untuk menentukan kriteria kualitas produk yang telah dikembangkan, data yang diperoleh dari kuesioner tentang tanggapan siswa diubah dulu menjadi data interval yaitu sangat baik $=5$ $(100 \%$ sesuai dengan unsur-unsur yang ada dalam pertaanyaan/pernyataan itu), baik $=4$ $(80 \%$ sesuai dengan unsur-unsur yang ada dalam pertanyaan/pernyataan itu), cukup $=3$ (60\% sesuai dengan unsur-unsur yang ada dalam pertanyaan/pernyataan itu), kurang $=2$ (40\% sesuai dengan unsur-unsur yang ada dalam pertanyaan/pernyataan itu), sangat kurang $=1(20 \%$ sesuai dengan unsur-unsur yang ada dalam pertanyaan/pernyataan itu).

Dalam kuesioner diberikan lima pilihan untuk memberikan tanggapan tentang produk multimedia berbasis komputer yang dikembangkan, yaitu: sangat baik (5), baik (4), cukup (3), kurang (2), dan sangat kurang (1). Seandainya siswa memberi tanggapan "sangat baik" pada suatu butir pertanyaan/pernyataan, maka skor butir pertanyaan tersebut sebesar " 5 ', demikian seterusnya.

Dalam penelitian ini, ditetapkan nilai kelayakan produk minimal "C", dengan kategori "cukup", sebagai hasil penilaian baik dari ahli media, ahli materi dan siswa. Jika hasil penilaian akhir (keseluruhan) pada aspek media dan aspek materi dengan nilai minimal "C" (cukup) oleh para ahli, dan jika hasil penilaian akhir (keseluruhan) dengan nilai minimal "C" (cukup) oleh siswa maka produk hasil pengembangan tersebut sudah dianggap layak digunakan sebagai sumber belajar.

Mencari skor rata-rata (rerata skor) dalam memberikan penilaian terhadap produk yang telah dikembangkan digunakan rumus:

$$
\overline{X i}=\frac{\sum X}{n}
$$

Keterangan:

$\overline{X i} \quad=$ Skor rata-rata.

$\sum \mathrm{X}=$ Jumlah Skor.

$\mathrm{N} \quad=$ Jumlah responden.

\section{Hasil Penelitian dan Pembahasan}

Studi Pendahuluan

Pengembangan multimedia interaktif diawali dengan melakukan studi pendahuluan pada bulan April 2012 di SDN Lempuyangan 1
Yogyakarta. Studi pendahuluan terdiri atas studi pustaka dan studi lapangan. Adapun data yang diperoleh dari studi pendahuluan ini yaitu:

\section{Studi Pustaka}

Berdasarkan studi pustaka terhadap teori-teori tentang multimedia interaktif dan hasil penelitian terdahulu diketahui bahwa penggunaan multimedia interaktif dalam pembelajaran memberikan manfaat yang begitu tinggi terhadap proses pembelajaran seperti meningkatkan pemahaman konsep dan meningkatkan prestasi belajar peserta didik.

\section{Studi Lapangan}

Hasil studi lapangan yang dilakukan oleh peneliti dengan penyebaran angket terhadap pendidik dan peserta didik serta melakukan wawancara terhadap pendidik diperoleh data bahwa pembelajaran IPS dianggap sulit oleh peserta didik karena banyak hapalan, pendidik hanya mengandalkan variasi metode belajar saja dalam pembelajaran IPS dan jarang menggunakan media karena keterbatasan media yang dimiliki di SDN Lempuyangan 1 Yogyakarta, pendidik mengalami kesulitan dalam hal penyampaikan materi tentang peristiwa penting proklamasi kemerdekaan kepada peserta didik begitu juga sebaliknya dikarenakan materi tersebut tergolong kejadian masa lalu, di SDN Lempuyangan 1 Yogyakarta terdapat laboratorium komputer yang difungsikan hanya untuk pembelajaran TIK dan peserta didik khususnya kelas $\mathrm{V}$ sudah terbiasa menggunakan komputer secara mandiri.

Pendidik dan peserta didik membutuhkan media dalam bentuk multimedia interaktif untuk pembelajaran IPS.

Desain Pengembangan Produk

Pada tahap pengembangan produk, melakukan kegiatan diantaranya adalah: a) Membuat flowchart dan storyboard sebagai tampilan atau gambaran suatu multimedia interaktif yang akan diproduksi. Secara lengkap flowchart dan storyboard dapat dilihat pada lampiran; b) mengumpulkan bahan-bahan yang diperlukan diantaranya adalah buku paket pembelajaran IPS SD kelas V yang membahas tentang peristiwa sekitar proklamasi, artikel lain yang sesuai dengan materi; c) menyiapkan materi pendukung seperti menyiapkan musik instrumen, membuat gambar dan animasi dan menyiapkan teks; d) menentukan program yang digunakan dalam membuat multimedia inter- 
aktif yaitu AutoPlay Media Studio 7.0, Adobe Flash Professional CS5, Adobe Photoshop 8.0; e) perakitan atau penggabungan bahan-bahan meng-gunakan program AutoPlay Media Studio 7.0 sehingga menghasilkan multimedia interaktif awal; f) melakukan pengemasan ke dalam $\mathrm{CD}$ untuk mempersiapkan langkah selanjutnya yaitu melakukan evaluasi terhadap produk yang dikembangkan.

Secara garis besar produk multimedia hasil pengembangan tahap awal berisi: Halaman pembuka, yang berisi opening program, judul " Pembelajaran IPS Kelas V SD Semeter Genap" dan "Pokok Bahasan Peristiwa Sekitar Proklamasi". Menu Utama, terdapat tombol petunjuk penggunaan program, materi pembelajaran, profil, kompetensi dan latihan.

Kompetensi yang berisikan standar kompetensi, kompetensi dasar dan indikator ketercapaian. Materi yang disajikan meliputi, pertemuan di Dalat, Menanggapi kekalahan Jepang, peristiwa Rengasdengklok, perumusan teks proklamasi, Detik-detik Proklamasi Kemerdekaan 17 Agustus 1945.

Latihan, untuk mengukur tingkat pemahaman materi yang disajikan setelah itu akan keluar sekor hasil tes yang telah dikerjakan.

Bahan penarik perhatian, berupa perpaduan antara animasi, teks, gambar, foto, warna, tampilan grafis, suara dan musik dengan tombol-tombol navigasi interaktif untuk membuat pembelajaran menjadi lebih interaktif dan menarik.

\section{Hasil Validasi Ahli Media}

Dalam pelaksanaannya ahli media mencoba menggunakan dan mencermati produk didampingi oleh peneliti, kemudian ahli media instruksional memberikan penilaian, komentar dan saran revisi yang berkaitan dengan aspek pemrograman dan aspek tampilan. Seluruh data kuantitatif skala lima dikonversi ke dalam data kualitatif untuk menentukan kriteria akhir dari masing-masing aspek baik data dari ahli media, ahli materi dan siswa. Data penilaian ahli media terhadap multimedia pembelajaran interaktif adalah sebagai berikut:

Tabel 1. Data Hasil Penilaian Ahli Media

\begin{tabular}{ccc}
\hline No. & Aspek Penilaian & Skor \\
\hline 1 & Pemrograman & 4,17 \\
2 & Tampilan & 4,30 \\
& Mean & 4,25 \\
\hline
\end{tabular}

Setelah ahli media mempelajari produk multimedia pembelajaran yang dikembangkan oleh peneliti, ahli media memberikan penilaian terhadap produk tersebut. Penilaian tersebut dijaring dengan mengisi angket skala likert. Ahli media memberikan penilaian mengenai kelayakan produk yang dikembangkan, diperoleh rerata penilaian sebesar 4,25 (kategori sangat baik) sehingga, dari sisi media dinyatakan "layak" sebagai media pembelajaran.

\section{Data Validasi Ahli Materi}

Data validasi ahli materi di peroleh dengan cara memberikan produk dalam bentuk CD dilengkapi print out materi, dan menggunakan angket skala likert yang mencakup aspek pembelajaran dan aspek materi/isi. Terdapat 2 aspek yang dinilai oleh ahli materi yaitu: aspek pembelajaran dan aspek materi/isi. Deskripsi penilaian ahli materi terhadap multimedia interaktif hasil pengembangan sebagai berikut:

Tabel 2. Data Hasil Penilaian Ahli Materi

\begin{tabular}{clc}
\hline No. & Aspek Penilaian & Skor \\
\hline 1 & Pembelajaran & 4,20 \\
2 & Materi & 4,33 \\
& Mean & 4,26 \\
\hline
\end{tabular}

Berdasarkan penilaian ahli media terhadap dua aspek pada Tabel 2 diperoleh rerata penilaian sebesar 4,26 (kategori sangat baik) sehingga, dari sisi materi dinyatakan "layak" sebagai materi pembelajaran dan dapat diujicobakan pada tahap berikutnya yaitu uji coba satu-satu dengan revisi sesuai saran.

Hasil Uji Coba Satu-satu (One To One Evaluation)

Pertama-tama pengembang menjelaskan produk yang sedang dikembangkan kepada kedua siswa tersebut serta menjelaskan prosedur uji coba tersebut. Kemudian siswa dipersilahkan mencoba multimedia pembelajaran tersebut. Pada saat uji coba, siswa tampak berkonsentrasi dan antusias dalam mencoba multimedia pembelajaran tersebut. Setelah dirasa cukup, kemudian pengembang membagi angket dan menjelaskan sistematika pengisian angket kepada 3 orang siswa tersebut. Untuk mempermudah siswa dalam mengisi angket yang diberikan, pengembang mengubah kata-kata pada butir-butir angket yang disesuaikan dengan kemampuan pemahaman usia siswa kelas V SD. Hal tersebut dilakukan tanpa mengubah maksud dan isi dari angket tersebut. Ada siswa yang menanyakan komponen angket yang menurutnya kurang jelas. Kemudian siswa asyik meng- 
isi angket berdasarkan tanggapan dan masukan mereka secara objektif terhadap multimedia ini.

Tabel 3. Data Hasil Uji Coba Satu-satu

\begin{tabular}{clc}
\hline No. & Aspek Penilaian & Skor \\
\hline 1 & Pembelajaran & 4,05 \\
2 & Materi & 4,25 \\
3 & Media & 4,33 \\
& Mean & 4,23 \\
\hline
\end{tabular}

Siswa dalam menggunakan multimedia pembelajaran IPS ini terlihat antusias. Ini berarti siswa begitu tertarik untuk menggunakan media ini sebagai sumber belajar dengan komponen-komponen yang terdapat di dalamnya dan begitu menikmati dalam menggunakan multimedia interaktif untuk mata pelajaran IPS kelas V SD. Sesuai dengan tabel konversi data kuantitatif ke data kualitatif termasuk dalam kriteria "Sangat Baik".

\section{Hasil Uji Coba Kelompok Kecil (Small Group Evaluation)}

Pertama-tama pengembang menjelaskan produk yang sedang dikembangkan kepada para siswa tersebut serta menjelaskan prosedur uji coba. Kemudian siswa dipersilahkan mencoba media tersebut. Setelah dirasa cukup, kemudian pengembang membagi angket dan menjelaskan sistematika pengisian angket tersebut kepada 10 orang siswa tersebut. Ada beberapa siswa menanyakan komponen angket yang menurutnya kurang jelas. Kemudian siswa sibuk mengisi angket berdasarkan tanggapan dan masukan mereka secara objektif terhadap media ini. Secara umum proses uji coba berlangsung cukup kondusif, karena jumlah subjek yang masih sedikit dan pengembang dapat mengontrol dengan baik dengan didampingi oleh guru kelas $\mathrm{V}$.

Tabel 4. Data Hasil Uji Coba Kelompok Kecil

\begin{tabular}{clc}
\hline No. & Aspek Penilaian & Skor \\
\hline 1 & Pembelajaran & 4,00 \\
2 & Materi & 4,15 \\
3 & Media & 4,22 \\
& Mean & 4,14 \\
\hline
\end{tabular}

Hasil data yang diperoleh menunjukan bahwa siswa dalam uji coba tampak serius melihat dan menggunakan media tersebut dengan memperhatikan penjelasan dari pengembang dan guru. Siswa membaca, dan mencoba menggunakan media dengan sebaik mungkin urut dari satu tampilan ke tampilan yang lain. Sesuai dengan tabel konversi data kuantitatif ke data kualitatif termasuk dalam kriteria "Baik".

\section{Hasil Uji Coba Lapangan (Field Evaluation )}

Pembagian angket dilakukan beberapa saat setelah siswa dirasa cukup dalam mencoba media tersebut. Untuk mempermudah siswa dalam mengisi angket yang diberikan, pengembang mendampingi siswa dan memberikan penjelasan tentang aspek-aspek yang ada di dalam angket. Pengembang kemudian menjelaskan sistematika pengisian angket kepada siswa. Meski begitu masih tampak beberapa siswa yang menanyakan perihal komponen-komponen angket yang dirasa belum jelas. Setelah itu, siswa juga diminta untuk mengisi komentar dan saran bila dikehendaki. Kemudian siswa tampak sibuk mengisi angket dengan tanggapan dan pertimbangan mereka secara objektif dan secara keseluruhan, uji coba lapangan ini cukup kondusif sampai uji coba berakhir.

Hasil data yang diperoleh menunjukan bahwa siswa dalam uji coba serius melihat dan menggunakan media tersebut dengan memperhatikan penjelasan dari pengembang dan guru. Siswa aktif memahami isi materi pada program. Siswa begitu tertarik untuk menggunakan media ini sebagai sumber belajar dengan komponen-komponen yang terdapat di dalamnya dan sangat senang dan begitu menikmati dalam menggunakan multimedia pembelajaran IPS untuk kelas V SD. Sesuai dengan tabel konversi data kuantitatif ke data kualitatif termasuk dalam kriteria "Baik".

Tabel 5. Data Hasil Uji Coba Lapangan

\begin{tabular}{clc}
\hline No. & Aspek Penilaian & Skor \\
\hline 1 & Pembelajaran & 4,01 \\
2 & Materi & 4,22 \\
3 & Media & 4,06 \\
& Mean & 4,08 \\
\hline
\end{tabular}

Kajian Produk Akhir

Pengembangan multimedia interaktif ini menggunakan program Autoplay 7.0, Adobe Flash CS5 dan Adobe Photoshop CS dengan pokok bahasan peristiwa sekitar Proklamasi untuk kelas V SD/MI. Multimedia interaktif yang dikembangkan ini telah melalui tahapantahapan pengembangan diantaranya adalah studi pendahuluan, pengembangan desain pembelajaran, pengembangan produk dan evaluasi produk sehingga menghasilkan produk multimedia interaktif yang diharapkan yaitu layak sebagai media pembelajaran dan memiliki efektivitas terhadap hasil belajar IPS.

Berdasarkan hasil analisis data pada uji coba menunjukkan bahwa: 
Hasil penilaian dari ahli media terhadap kelayakan multimedia interaktif mencapai skor rerata 4,25 dengan kategori sangat baik sehingga multimedia interaktif berdasarkan penilaian dari ahli media adalah layak sebagai media pembelajaran IPS dan siap untuk diuji coba satu-satu.

Hasil penilaian dari ahli materi terhadap kelayakan multimedia interaktif mencapai skor rerata 4,26 dengan kategori sangat baik sehingga multimedia interaktif layak sebagai media pembelajaran IPS dan siap untuk diuji coba satu-satu.

Hasil penilaian dari peserta didik terhadap kelayakan multimedia interaktif pada uji coba lapangan mencapai skor rerata 4,08 dengan kategori baik sehingga multimedia interaktif yang dikembangkan berdasarkan penilaian dari peserta didik pada uji coba lapangan adalah layak sebagai media pembelajaran IPS kelas V sekolah dasar.

Kelebihan dari multimedia interaktif adalah dapat menggabungkan berbagai macam media juga dapat digunakan untuk pembelajaran mandiri maupun klasikal sehingga peserta didik dengan berbagai tingkatan kemampuan dapat menggunakannya tanpa merasa kesulitan kerena dilengkapi dengan petunjuk penggunaan dan multimedia interaktif ini menggunakan model sajian tutorial yang berfungsi memberikan tutorial layaknya seorang pendidik. Di samping itu multimedia interaktif ini sangat praktis dikarenakan menggunakan system autorun dan file berbentuk exe sehingga dapat diputar di komputer manapun dengan spesifikasi tertentu tanpa harus mengistal terlebih dahulu.

\section{Simpulan dan Saran}

Simpulan

Berdasarkan dari hasil penelitian pengembangan multimedia interaktif ini, maka dapat disimpulkan sebagai berikut:

Berdasarkan hasil penilaian ahli media pada aspek pemrograman dan aspek tampilan rerata total sebesar 4,25 (sangat baik). Rincian rerata dari setiap aspek yaitu aspek pemprograman memperoleh rerata sebesar 4,17 (baik) dan aspek tampilan memperoleh rerata sebesar 4,30 (sangat baik), sehingga penilaian multimedia interaktif mata pelajaran IPS dengan pokok bahasan Peristiwa Sekitar Proklamasi tergolong "layak" digunakan sebagai media pembelajaran.
Berdasarkan evaluasi kualitas multimedia interaktif mata pelajaran IPS oleh Ahli materi pada aspek pembelajaran dan aspek materi/isi sebesar 4,26 (sangat baik). Rincian rerata dari setiap aspek yaitu aspek pembelajaran memperoleh rerata sebesar 4,20 (baik), dan aspek isi atau materi memperoleh rerata sebesar 4,33 (sangat baik). Berdasarkan data tersebut dapat diketahui bahwa pada aspek pembelajaran dan aspek materi atau isi, produk pengembangan yang berupa multimedia interaktif "layak" sebagai media pembelajaran IPS kelas V sekolah dasar.

Berdasarkan uji coba lapangan dalam hal ini adalah peserta didik atau siswa pada aspek pembelajaran, isi/materi, dan media sebesar 4,08 (baik). Rincian rerata dari setiap aspek yaitu aspek pembelajaran memperoleh rerata sebesar 4,01 (baik), aspek isi atau materi memperoleh rerata sebesar 4,22 (sangat baik), dan aspek media memperoleh rerata sebesar 4,06 (baik). Berdasarkan data tersebut dapat diketahui bahwa pada aspek pembelajaran, aspek isi atau materi dan aspek media, produk pengembangan yang berupa multimedia interaktif memperoleh kategori "layak" sebagai media pembelajaran IPS kelas V sekolah dasar

Saran Pemanfaatan, Disiminasi, dan Pengembangan Produk Lebih Lanjut

\section{Saran Pemanfaatan}

Bagi peserta didik yang baru pertama kali menggunakan multimedia interaktif secara mandiri, hendaknya pendidik memberikan pengarahan terlebih dahulu tentang cara penggunaannya walaupun multimedia interaktif ini di desain untuk pembelajaran mandiri bagi peserta didik dan sudah dilengkapi dengan fasilitas menu untuk petunjuk penggunaan.

Bagi sekolah, untuk pemanfaatan multimedia interaktif ini dalam pembelajaran diperlukan laboratorium komputer multimedia sehingga multimedia interaktif dapat berfungsi dan memberikan manfaat secara optimal.

Desiminasi

Multimedia interaktif ini dapat didesiminasikan yaitu melalui kerja sama dengan dinas pendidikan pemerintah terkait, melalui musyawarah pendidik mata pelajaran IPS, melalui pelatihan tentang media pembelajaran bagi pendidik SD, dan melalui berbagai forum lainnya sehingga multimedia interaktif yang dikembangkan ini dapat digunakan oleh seluruh sekolah SD/MI, khususnya untuk pembelajaran 
IPS kelas V dalam hal meningkatkan hasil belajar peserta didik.

\section{Pengembangan Produk Lebih Lanjut}

Kepada para peneliti yang mengambil judul yang relevan dengan penelitian ini, diharapkan dapat mengembangkan multimedia interaktif lebih lanjut baik dari segi keluasan, kedalaman dan keterkinian materinya sesuai dengan kurikulum yang berlaku sehingga menjadi salah satu sumber belajar yang baik untuk peserta didik.

\section{Daftar Pustaka}

Borg, W. R., \& Gall, M. D. (2003). Educational research: An introduction $\left(7^{\text {th }} \mathrm{ed}\right)$. New York: Longman.

Dick, W., Carey, L., \& Carey, J.O. (2005). The systematic design of instruction. $\left(6^{\mathrm{ed}}\right)$. New York: Person.
Kennedy, D. M., \& McNaught, C. (1997). Design elements for interactive multimedia. Australian Journal of Educational Technology, 13(1), 1-22. Diunduh pada tanggal 5 February 2013 dari http://www.ascilite.org.au/ajet/ajet13/k ennedy.html.

Sadiman, Arief S. (2006). Media pendidikan: pengertian, pengembangan, dan pemanfaatannya. Jakarta. Raja Grafindo Persada.

Sukardjo. (2008). Evaluasi pembelajaran. Handbook: PPs Universitas Negeri Yogyakarta.

Warsita, Bambang. (2008). Teknologi pembelajaran landasan dan aplikasinya. Jakarta. Rineka Cipta. 